\title{
The Analysis of Using Picture Sketch to Improve Drawing Ability of Preschooler Students
}

\author{
Hanita, Mahkamah Brantasari \\ \{nitahanita87@gmail.com ${ }^{1}$,brantasari@gmail.com ${ }^{2}$ \} \\ ${ }^{1,2}$ University of Widya Gama Mahakam, Jl. K. H. Wahid Hasyim No. 28 Samarinda, East Borneo
}

\begin{abstract}
The current isue talks about the use of picture sketch to improve the ability of preschooler drawing skill. It triggers the child physically, emotionally, and intellectually to share the ideas into drawing. Furthermore, it also useful to create a creative and fun activity between teacher and students in the class Therefore, this study aims to find out the use of picture sketch to improve the drawing ability of preschooler students. This research was conducted in three cycles. The result was obtained from recapitulation of three cycles. The data were collected by observation and documentation. Thus, the subjects were 15 children from age 4 to 5 years old. The result showed that the subject achievements was $80 \%$ with the detailed as follows: 1 ) The result from cycle I was $28.9 \%, 2$ ) the result ability of cycle II was $61.5 \%, 3$ ) the result of cycle II was $80.7 \%$. In addition, the cycle was continued untill three times as it had not reached the target research yet. It was only $28.9 \%$ in cycle I and finally reached $82.2 \%$ in cycle III. In conclusion, from those learning outcomes it was found that picture sketch could improve the ability of preschooler students'drawing ability.
\end{abstract}

Keywords: Skill drawing and the picture sketch

\section{Introduction}

Parents' knowledge of early childhood education is education that teaches the ability to read, write and count. Though there are many basic abilities that must be possessed by children that need to be stimulated, especially in fine motor skills. At the beginning of the child sharpening fine motor skills, the child first performs activities that make the ability of muscles to improve on one of them is the child's favorite scribbling with any media and materials[1]. This behavior sometimes makes parents angry so often scold what children do. However, many researchers argue that the images and scribbles made by children are considered as a mirror of the development of children's representation[2]. Drawing is one approach that is used for the study of cognitive development, assessing images of children can see children's understanding of the world.[3]

In general, early childhood educationalists address issues of aesthetics in relation to the display of artwork, but have yet to acknowledge young children's experiences surrounding the act of art work display and its impact on them as individuals. [4] maintains that children's artwork is a reflection of self-expression, meaning that teachers need to be cognizant of their responses to children's artistry.[5]

Luquet (1927) believed that image activity evolved gradually from just training to a form of structured play. In his view, the origin of the trace image is spontaneous, but vulnerable to 
the influence of adults[6]. The child, finds pleasure in the release of motor and lines made, which is seen as an imitation of adult writing. The transition from scribbling as motor activity to scribbling controls and, then, to the actual image, where there is an expression of representative purpose, occurs spontaneously. [7] argues that when children begin to pay attention to some form of analogy between the traces they leave behind from paper and the forms of real objects, it leads them to regard their images as original representations of the world, to the point of interpreting them.[8]

Drawing of one of the facilities for children to convey the problem and expressing emotion , play with a color that is also helping a child to mengembanggkan the ability done this in a while. The result of drawing for children is part of ekperimen who do not pay no mind the outcome would be. Children played with colors and drawing interesting and preferred[9].

According to Lowenfeld there are four subcategories of graffiti, the first three relating to kinesthetic experience and then going into imaginative thinking. The first sub-category has no control, the art looks chaotic and very irregular. the second is streaks that appear elongated and have many repetitive movements, this shows the child gets more control. The circular motion determines the third subcategory and suggests that the child has better motor control[10]. The fourth stage is naming graffiti. When a child begins to mention the graffiti, it is open to allow them to tell stories that can lead to insights about the conflict or trauma in the child's life. Children usually have a limited vocabulary that can limit their stories. [11]

Sketches are generally understood as fast images, namely images that are made in a relatively short time by displaying essential line elements on the object displayed. Smith stated that sketches or sketches derived from English sketch, generally known as a chart or plan for a painting[12][13]. Usually, sketches are made by designers or artists in making work designs, either as a chart or plan for a painting, or in other art works[14]. In Pangarso's opinion, if sketches are made with relatively fast time with simple and efficient lines without the use of detail, then drawing (drawing) is a work of art that presents an object in detail, with a pencil, pen, and so on. However, the scribbled results of these children in a particular media are more commonly said as drawing works, although sometimes the scratch is simple, made in a relatively fast or long time, and lacking in detail[15]. This is because when doing the scribbling activity, a child does not think that his work is a design drawing for the next work or is a finished work which they call sketch. Lowenfeld and Brittain (1982: 7) reveal that artistic activities for a child are primarily a way of expressing expression. Thus, the scratches of children who make certain objects can be expressed as finished works in the form of images.[16]

In fact, when children do drawing activities, there are still many children who have difficulty making a drawing, in the end the child becomes a lazy person to draw. Teachers are required to be able to provide an easy method to teach children to be able to draw. Sketch techniques that are taught to children in a simple and easy manner are expected to be able to give an influence in improving children's creativity. Children's drawing skills become more creative and effective as well as easy and fun children's learning experiences.

\section{Method}

The implementation of this research was at Tunas Harapan Samarinda Kindergarten. A total of 15 children were the focus of this study. Children participate in activities given directly by doing drawing activities and explaining the images that have been made. The perperan teacher directs the child by giving examples of drawing with examples of simple sketches that are easy 
for children to follow. The design of this study refers to the Kemmis and McTaggart models which include 4 stages: (i) planning (ii) implementation of actions (iii) observation (iv) reflection.[17]

This study discusses and reflects in depth the process of improving children's drawing skills, whose activities include; teacher performance, interaction between teacher and child, interaction between child and friend, and child with work. Planning research includes formulating problems, determining goals, methods and making action plans. The implementation of the research seeks to implement planning that has been made in real terms without changing. The implementation of observations is done by observing the results of the teaching and learning process. Reflection is carried out by studying in depth and considering success and recommending what actions should be taken in the next cycle.

The procedure for implementing this study was designed by creating a research scenario to achieve the desired goals. Provides a variety of simple sketch drawings that are close to children, especially images of animals, fruit, solar systems and nature. How to collect data by observing the process and results of research, as well as documenting the results of drawing children.

Indications of the ability to draw children's results are assessed based on criteria; 1) children's ability to draw, 2) image similarity, 3) active, 4) neatness of drawing, 5) beauty, 6) combination of images. This criterion becomes a measuring tool to show a situation that occurs in the process of improvement and change. The achievement of the success target of this study if it reaches $\geq 80 \%$.

\section{Findings and Discussion}

The picture child offer freshness, and courage, the we as adults may be difficult to be imitated by an.Gardner ( 1982 ) speak about the year a preschool as the golden creativity, the day when every child interested in art. This study on which to base observation is by gathering, describe and analyzes the drawings and with narrative of children. Gardner said impressed by means children approximating a drawing them and whatever their they produce. Observation, which constitutes the essential part of research is, expressing much experience this with that which belongs to children [4]. Research on outcomes and describe the findings , analysis and direfleksi to know in need and excess each learning activities.

\subsection{Cycle 1}

Table 1 Results of Cycle 1 Observations

\begin{tabular}{lllll}
\hline Assessment criteria & $1^{\text {st }}$ meeting & $2^{\text {nd }}$ meeting & $3^{\text {rd }}$ Meeting & Average \\
\hline Children's Ability to Draw & $26.7 \%$ & $26.7 \%$ & $33.3 \%$ & $28.9 \%$ \\
Image similarity & $20 \%$ & $33.3 \%$ & $40 \%$ & $31.1 \%$ \\
Active & $20 \%$ & $33.3 \%$ & $40 \%$ & $31.1 \%$ \\
Neatness of Drawing & $20 \%$ & $26.7 \%$ & $33.3 \%$ & $26.7 \%$ \\
Beauty & $20 \%$ & $26.7 \%$ & $26.7 \%$ & $24.5 \%$ \\
Image Combination & $20 \%$ & $33.3 \%$ & $40 \%$ & $31.3 \%$ \\
Total & $21.1 \%$ & $30 \%$ & $35.5 \%$ & $28.9 \%$ \\
\hline
\end{tabular}

Planning on a cycle 1 it is planned activities of the universe. Titled Was drafted in. Research planning the plan implementation of the learning (RPPH). Daily In RPPH consisting of; 1 ), activities 2 ) material habits 3 ) core learning material, 4 ) assessment plan 5) the purpose of learning, 6 ) assessment techniques. The observations of the process and learning activities carried out at the time and after the. activities take Assess the work of kids and observe for little. 
The results obtained on recapitulation of the success of the cycle the researcher can be seen on table 1 .

In table 1 draw the results of observations made on each assessment criterion and viewed from the overall ability. the average achieved in cycle 1 is $28.9 \%$. The assessment criteria. on resemblances the pictures active and combination of pictures rata-rata got the same high between the assessment criteria and the others $31.1 \%$

Reflections on the results of research in cycle 1 which need attention as follows (a) The teacher must master how to draw the picture that he wants to teach, (b) The teacher gives motivation to children in participating in activities, (c) Teachers need to direct students in carrying out activities, (d) Teachers need to give examples to children who have difficulty in using tools and materials, and (e) Teachers need to actively direct children in carrying out activities

In the research activities 1 cycle it is the true the the conversation anatra. childrenIt is on the social skills and friendship. Because. Among children said Shugar (1988) one of the functions of the group was to study what it means to be peers. [4]The cycle 1 acquired at to a criterion first attained $28.9 \%$ or around 4 children. criterion both reached $31.1 \%$ or about 5 children . third criteria reached $31.1 \%$ or about 5 children . fourth criteria reached $26.7 \%$ or around 4 children . fifth criteria reached $24.5 \%$ or about 3 children . sixth criteria reached 31.1 $\%$ or about 5 children . these results not reached target planned and continued this research into a cycle 2 .

\subsection{Cycle 2}

Table 2 Results of Cycle 2 Observations

\begin{tabular}{lllll}
\hline Assessment Criteria & $1^{\text {st }}$ Meeting & $2^{\text {nd }}$ Meeting & $3^{\text {rd }}$ Meeting & Average \\
\hline Children's Ability to Draw & $46.7 \%$ & $60 \%$ & $66.7 \%$ & $57.8 \%$ \\
Image similarity & $53.3 \%$ & $60 \%$ & $66.7 \%$ & $60 \%$ \\
Active & $53.3 \%$ & $53.3 \%$ & $60 \%$ & $55.5 \%$ \\
Neatness of Drawing & $53.3 \%$ & $66.7 \%$ & $66.7 \%$ & $62.2 \%$ \\
Beauty & $60 \%$ & $66.7 \%$ & $73.3 \%$ & $66.6 \%$ \\
Image Combination & $60 \%$ & $66.7 \%$ & $73.3 \%$ & $66.6 \%$ \\
Total & $54.4 \%$ & $62.2 \%$ & $66.7 \%$ & $61.5 \%$ \\
\hline
\end{tabular}

The research phase in cycle 2 is the same as cycle 1 . Make an action plan in the form of RPPH and prepare a sketch drawing that will be used as an example of drawing learning. But before carrying out the activities in cycle 2 the researcher conducts a briefing to the teacher to better master and attract children. this is based on the results of reflection on cycle 1 . The observation phase is also carried out during the learning process and the work of the child. The results obtained in cycle 2 have increased. this is clearly outlined in the table 2.

Reflections on this second cycle of research found the following notes: (a) Children's activity starts to increase compared to cycle 1, (b) Children's ability to follow the model also increases, (c) There are still children who have difficulty in using learning tools and materials.

From the results above. it can be seen that the improvement of the learning process is mainly the activity and enthusiasm of children in the learning process. In cycle 2 . children who have difficulty in using learning tools and materials are reduced. According to Tassoni and Hooker (2000) feel that children rarely ask for help when they paint or draw. in this study the interaction with the teacher about the contents of the picture occurs regularly. not only helps stimulate the subject. important but also allows adults to model. strengthen and support children's language.[4] 
The results obtained in the second cycle of the assessment criteria have not reached the planned target. so this research is continued to cycle 3 .

Cycle 3

The stage of implementation of research in cycle 3 is the same as the previous cycle. The results obtained in cycle 3 are as table 3 .

Table 3 results of cycle 3 observations

\begin{tabular}{lllll}
\hline Assessment criteria & $1^{\text {st }}$ Meeting & $2^{\text {nd }}$ Meeting & $3^{\text {rd }}$ Meeting & Average \\
\hline Children's Ability to Draw & $80 \%$ & $80 \%$ & $86.7 \%$ & $82.2 \%$ \\
Image similarity & $73.3 \%$ & $80 \%$ & $86.7 \%$ & $80 \%$ \\
Active & $80 \%$ & $86.7 \%$ & $86.7 \%$ & $84.5 \%$ \\
Neatness of Drawing & $73.3 \%$ & $80 \%$ & $86.7 \%$ & $80 \%$ \\
Beauty & $86.7 \%$ & $80 \%$ & $80 \%$ & $82.2 \%$ \\
Image Combination & $80 \%$ & $86.7 \%$ & $86.7 \%$ & $84.5 \%$ \\
Total & $78.8 \%$ & $82.2 \%$ & $85.6 \%$ & $82.2 \%$ \\
\hline
\end{tabular}

The findings in this cycle 3 study are the emergence of an increase in children's imagination abilities. Children not only draw according to learning. but children add other images to the work of children. And children show a more active attitude and enthusiasm in accordance with the teacher's direction.

The results obtained in cycle 3 have reached the research target of $\geq 80 \%$. in the second and third meetings in cycle 3 it has shown an increase of all assessment criteria. So in the third cycle. the study was completed which reached $82.2 \%$.

Drawing is an activity that is very popular with children. especially in early childhood. Most of them like to draw. and they do it widely to serve various purposes during their play or in other daily activities. Widely accepted activities for children of this age by parents. educators and psychologists. However. parents and teachers adopt various views about the nature and importance of this activity; this view determines whether and to what extent they grow and help use it at home or at school. They may also think that drawing is a means of expression. but not as important and useful as writing and reading. Matthews (2003) argues that some see the construction of realistic images by children as indications of intelligence. and their images are used primarily as a means to evaluate their development based on certain stages of development.[18]

Drawing is a comprehensive activity that includes cognitive. affective. and psycho-motoric processes. Cognitive is the ability to think and analyze a truth based on rational thinking. Affective is the ability to process sensitivity to feelings and emotions based on a relative truth. While psycho-motorism is the integration of the ability of the brain and limbs to translate something in the mind into a visual form.[19]

The ability of the teacher to deliver the material also affects the increase in the ability to draw children's creativity. Teachers have many roles by actively supporting and communicating well so that they can foster imagination in children. Cooperation in children is also formed because of the interaction and discussion between children. So that the implementation of the study went well. Although there are still obstacles. there are difficulties in focusing children's attention.

From the results obtained from cycle 1 to cycle 3 the ability of children always increases. One reason for the increase in ability is that children know and master learning methods during the running cycle. So the ability to draw children's creativity in kindergarten shows an increase in learning achievement well. 
Therefore. if the teacher or researcher uses images as a tool to sharpen the drawing skills of children either to classify children into developmental stages or to identify specific artistic skills and emotions they use them as a step towards developing writing. and recognizing goals and ways in which children children use it or its potential to function as a learning and teaching tool.[18]

\section{Conclusion}

Based on the results of the research from the first cycle to the third cycle. it can be concluded that the results of children's creativity in drawing skills can be improved through sketch drawings. This is indicated by the achievement of research success indicators that reached $\geq$ $80 \%$ and the results of the first cycle of observations $28.9 \%$ increased in the second cycle $61.5 \%$ then continued to the third cycle reaching $82.2 \%$. The activity of children in participating in learning is also seen to be increasing because the teacher has a role by giving active support and communicating well so as to grow the imagination of children. increased ability is that children know and master learning methods during the process of implementing the cycle.

\section{References}

[1] I. D. Cherney et al.. "Educational Psychology: An Children's Drawings : A mirror to their minds Children's Drawings : A mirror to their.” no. October 2014. pp. 37-41.

[2] R. Quaglia. C. Longobardi. N. O. Iotti. and L. E. Prino. "Infant Behavior and Development Brief Report A new theory on children's drawings : Analyzing the role of emotion and movement in graphical development." Infant Behav. Dev.. vol. 39. pp. 81-91. 2015.

[3] I. D. Cherney. C. S. Seiwert. T. M. Dickey. and J. D. Flichtbeil. "Children's drawings: A mirror to their minds." Educ. Psychol.. vol. 26. no. 1. pp. 127-142. 2006.

[4] E. Coates and A. Coates. "Young children talking and drawing." vol. 14. no. 3. pp. 221241. 2006.

[5] D. Twigg and S. Garvis. "Exploring Art in Early Childhood Education." Int. J. Arts Soc.. vol. 5. no. 2. pp. 193-204. 2010.

[6] N. Rao. B. Richards. J. Sun. A. Weber. and A. Sincovich. "Early childhood education and child development in four countries in East Asia and the Pacific." Early Child. Res. $Q$.. vol. 47. pp. 169-181. 2019.

[7] E. Yates and E. Twigg. "Developing creativity in early childhood studies students." Think. Ski. Creat. vol. 23. pp. 42-57. 2017.

[8] R. Quaglia. C. Longobardi. N. O. Iotti. and L. E. Prino. "A new theory on children's drawings: Analyzing the role of emotion and movement in graphical development." Infant Behav. Dev.. vol. 39. no. May. pp. 81-91. 2015.

[9] M. Kaczmarczyk. K. Wingenfeld. L. K. Kuehl. C. Otte. and K. Hinkelmann. "Childhood trauma and diagnosis of major depression: Association with memory and executive function." Psychiatry Res. vol. 270. pp. 880-886. 2018.

[10] N. M. Wessman-Enzinger. "Grade 5 children's drawings for integer addition and subtraction open number sentences.” J. Math. Behav.. 2018.

[11] W. W. Children. "Working With Children And Their Drawings By Rebecca Stolley 
University of Wisconsin - Superior." pp. 1-80.

[12] C. Katz. A.-L. Klages. and L. Hamama. "Forensic interviews with children: Exploring the richness of children's drawing and the richness of their testimony." Child. Youth Serv. Rev.. vol. 94. pp. 557-562. 2018.

[13] M. B. Ligorio. N. H. Schwartz. G. D'Aprile. and D. Philhour. "Children's representations of learning through drawings." Learn. Cult. Soc. Interact.. vol. 12. pp. 133-148. 2017.

[14] M. Farokhi and M. Hashemi. "The Analysis of Children's Drawings: Social. Emotional. Physical. and Psychological aspects." Procedia - Soc. Behav. Sci. vol. 30. pp. 2219 2224. 2011.

[15] V. Oğuz. "The factors influencing childrens' drawings." Procedia - Soc. Behav. Sci. vol. 2. no. 2. pp. 3003-3007. 2010.

[16] R. Setyo. I. Artikel. M. P. Sarjana. P. Doktor. and P. Seni. "Jurnal Imajinasi." Harmonia. vol. X. no. 1. 2016.

[17] D. Septiwiharti. "Penggunaan Media Gambar Untuk Meningkatkan Hasil Belajar Siswa Kelas III Pada Mata Pelajaran PKn di SDN 05 Lakea Kabupaten Buol.” vol. 5. no. 4. pp. 54-67.

[18] M. Papandreou. "Communicating and Thinking Through Drawing Activity in Early Childhood." no. December. pp. 37-41. 2014.

[19] H. D. Waluyanto. D. Jurusan. and D. Komunikasi. "Peran Menggambar Dalam Mewujudkan.” vol. 3. no. 1. pp. 66-72. 2001. 